\title{
Lime Application Rates on Selected Soil Chemical Properties of Acidic Soils
}

\author{
Mekonnen Asrat \\ Department of plant science, Debre Markos University, Debre Markos, Ethiopia
}

\begin{abstract}
:
Liming has been recently started to amend acidic soils in the study area but meager information is available about effects of Dejen lime on soil properties. The objective of this study was to investigate the application dose effect of locally available liming material on selected chemical properties of Dystric Nitisol. Soil samples received 0, 1.1, 2.2, 3.3 and $4.4 \mathrm{t} \mathrm{ha}^{-1}$ Dejen lime and incubated for one month at constant moisture and temperature. Finally, its $\mathrm{pH}$, exchangeable acidity, $\mathrm{Al}, \mathrm{Ca}, \mathrm{Mg}, \mathrm{K}, \mathrm{Na}$, Mehlich 3 and water soluble $\mathrm{P}$ were estimated. Lime rates significantly $(\mathrm{p}<0.01)$ increased soil $\mathrm{pH}$, exchangeable $\mathrm{Ca}$, Mehlich 3 and water soluble $\mathrm{P}$ but exchangeable acidity and Al significantly $(\mathrm{p}<0.01)$ decreased. Application of $2.2 \mathrm{t} \mathrm{ha}^{-1}$ Dejen liming material increased soil $\mathrm{pH}$ and available $\mathrm{P}$ by 0.6 units and $9.2 \mathrm{mg} \mathrm{kg}^{-1}$, respectively but exchangeable acidity decreased by $0.72 \mathrm{cmol}_{(+)} \mathrm{kg}^{-}$ ${ }^{1}$. Thus, application of $\geq 2.2 \mathrm{t} \mathrm{ha}^{-1}$ lime alleviate acidity related problem of the soil for crop growth but supplementary nutrient (mainly P) is required for optimum crop yield. Application of $2.2 \mathrm{t} \mathrm{ha}^{-1}$ Dejen liming material substantially improves soil acidity related problems but supplementary soil nutrient is essential to increase crop yield in the study area.
\end{abstract}

Keywords: Dejen, exchangeable acidity, lime incubation, Nitisol

DOI: $10.7176 / \mathrm{JNSR} / 12-1-02$

Publication date: January $31^{\text {st }} 2021$

\section{Introduction}

Soil acidity is the major limiting factor for sustainable agricultural production in many parts of the world (Sumner and Noble, 2003). Low phosphorus (P) availability and a high $\mathrm{P}$ fixation by huge quantities of aluminum (Al) and iron (Fe) oxides are characteristic of highly weathered acid soils in the tropics (Keerthisinghe et al., 2001). Large amount of iron and aluminum oxides rapidly react with applied phosphate and make it less soluble in the acidic soils (Bolan et al., 2003). Acid soil infertility is related with toxicities of Al and manganese (Mn) and deficiencies of calcium and magnesium (Foy, 1984; Bolan et al., 2003). The pH of acidic soils is commonly buffered by Aloxide which dissolves upon further acidification and gradually cation exchange sites of the soils are saturated with exchangeable Al.

Soils of Gozamin and Senan Districts of Eastern Gojam zone and Awi zone in Amhara region, Nedjo, Diga, Gimibi and Bedi of Oromia region, Chencha, Sodo and Endibir of South Nation and Nationality People (SNNP) are intensively affected by soil acidity (Minstry of Agriculture and Rural Development, 2006). Soil pH negatively affects the solubility and availability of $\mathrm{P}$ and Mo. Moreover, $\mathrm{Al}$ and $\mathrm{Mn}$ become highly soluble in low $\mathrm{pH}$ soils and can reach toxic level which inhibits nutrient uptake. Manganese minerals are highly soluble when soil $\mathrm{pH}$ drops below 5.2 (Upjohn et al., 2005).

Crop growth is negatively affected on strongly and moderately acidic soils (FAO, 2006). Furthermore, decomposition of organic matter is highly reduced in strongly acidic soils, thus the availability of plant nutrients is highly affected (Whitehead, 2000; Bolan et al., 2003). As much as 45\% of the cultivated lands of Amhara National Regional State are moderate to strongly acidic in their reaction (IOANRS, 2006). In tropical areas, soil acidity is a major problem to improve wheat and maize yield due to aluminum toxicity and phosphorus deficiency (Agriculture Information Center, 2002; Kisinyo et al., 2005; Upjohn et al., 2005). Similarly, wheat productivity of the Amhara region is lower than the national average due to intensive chemical degradation of soils and frequent drought, (CSA, 2005; 2006; 2007; Ashenafi, 2008).

Phosphorus is the main essential plant nutrient after nitrogen; it has a function in energy transfer as ATP, regulation of enzymatic reactions, transferring genetic materials, synthesis of nucleic acids and phospholipids (Wissuwa, 2003; Devers, 2011; Marschner, 2012). However, most plants which grow in acidic soils are P deficient and show low yield response to fertilization since $\mathrm{P}$ availability is determined by reactions on the sorption sites of soil regulating the $\mathrm{P}$ concentration in soil solution and adsorption-desorption reactions (Agbenin, 1996; Holford, 1997; Sato, 2003). Most soils of Ethiopian highlands are depleted in their basic cations but rich in sesquioxides, thus they strongly adsorb P and reduce its availability (Tekalign and Haque, 1991; Solomon et al.,2002; Birru and Heluf, 2003). Similarly, Birru and Heluf (2003) disclosed that 56\% of northwestern Ethiopian highlands soils are being categorized as having high $\mathrm{P}$ sorption capacity and requiring more than $150 \mathrm{mg} \mathrm{P} \mathrm{kg} \mathrm{soil}^{-1}$ to reach an adequate $\mathrm{P}$ level for crops. This $\mathrm{P}$ amount corresponds to about $300 \mathrm{~kg} \mathrm{ha}^{-1}$ in a $15-20 \mathrm{~cm}$ plough layer. About 70 to $75 \%$ of agricultural soils of Ethiopian highlands are phosphorus deficient, $36 \%$ of Ethiopian highlands soils were categorized under moderately P fixing while $1 \%$ of them had a high P fixation capacity (Buresh et al., 1997; 
Miressa and Robarge, 1999).

Acidic soils are lower in water and nutrient retention capacities thus reduce uptake of moisture and nutrient and low biotic activity (Kinraide, 2003, Pinkerton and Simpson, 1986). Furthermore, A1 and Mn ions toxicity of acidic soil restrict root growth (Foy, 1984; Pinkerton and Simpson, 1986). On the other hand, phosphorus deficiency is a major limiting factor for crop production in acidic soils of tropical highlands where soils adsorb large quantity of $\mathrm{P}$ and increase the fertilization requirement of crops (Sanchez et al., 1997; Sato, 2003). Therefore, $P$ deficiency of resource-poor farmer dominant fields could not be corrected by sole application of mineral fertilizer because of high P requirement of the soils and inflated price of the fertilizer (Sahlemedhin and Ahmed, 1983; Weil, 2000; Horst et al., 2001; Keerthisinghe et al., 2001; Nziguheba et al., 2002; Singh and Lal, 2005; Nziguheba, 2007). Furthermore, the global phosphate resource is predicted to be depleted within the next 50-100 years. Unfortunately in this era, high amount of $\mathrm{P}$ fertilizers are needed to produce more food and fiber to sustain the growing population (Gilbert, 2009).

Liming improves physicochemical properties of acidic soils. It raises $\mathrm{pH}$, thus decrease $\mathrm{Al}, \mathrm{Mn}$ and heavy metal toxicities but increases the availability of $\mathrm{P}$ and calcium $(\mathrm{Ca})$ thereby it creates favorable soil environmental conditions for growth of plant (Foy, 1984; Haynes, 1984; Naidu et al., 1990; Lungu et al., 1993; Holford et al., 1994; Slattery et al., 1995; Curtin and Syers, 2001; Bolan et al., 2003; Wildey, 2003; Rajkishore, 2005; Sato and Comerford, 2005; Mesfin, 2007; Fageria and Santos, 2008; Kisinyo et al., 2012). Similarly, crops respond positively to the application of lime through increasing soil $\mathrm{pH}$, exchangeable $\mathrm{Ca}$ and available $\mathrm{P}$ (Bolan et al., 2003; Henning, 2008). However, excess liming decrease crop yield that can be attributed to the effect it might have on the nutrient availability (mainly $\mathrm{P}$ ) and imbalances (Ca: $\mathrm{Mg}$ and $\mathrm{Ca}$ : $\mathrm{K}$ ratios) (Melakeberhan et al., 2001). Furthermore, excess liming increases $\mathrm{pH}$ to 5.6 to 6.2 which favors the incidence of take-all infection and reduces wheat grain yield (Thomason et al., 2001).

Dejen liming material is readily available and affordable in northwestern Ethiopian highlands. Moreover, there is extensive and thick Mesozoic limestone and gypsum sequences found in the Blue Nile River valley. However, meager information is available about the application rate effects of Dejen liming material on selected chemical properties of acidic soil. Therefore, this experiment was conducted to quantify the effect of Dejen lime on soil $\mathrm{pH}$, exchangeable acidity, $\mathrm{Al}, \mathrm{Ca}, \mathrm{Mg}, \mathrm{K}, \mathrm{Na}$, available $\mathrm{P}$ and water soluble $\mathrm{P}$.

\section{Materials and Methods}

\subsection{Experimental Materials}

Pit was opened at Enerat Kebele at geographical coordinate of $10^{0} 23^{\prime} 44^{\prime \prime} \mathrm{N}$ and $37^{\circ} 44^{\prime} 31^{\prime \prime}$ E to describe the morphological feature of the experiential soil as per World Reference Base (WRB) system (FAO, 1998). Moreover, three composite surface soil samples were collected at root depth from the cultivated land of. The samples were air dried and ground to pass through $2 \mathrm{~mm}$ sieve. The liming material was Dejen lime with $1.06 \%$ moisture content, $52 \%$ fineness factor, $91 \%$ purity and with neutralizing value of $50 \%$.

The bulk density was estimated from undisturbed soil using the core sample method (Blake, 1965). Soil pH was measured in water (1:2.5 soil: water ratio). Exchangeable acidity was extracted with $1 \mathrm{M} \mathrm{KCl}$ solution and then titrated with $0.02 \mathrm{M} \mathrm{NaOH}$ while exchangeable $\mathrm{Al}$ was determined from the same solution by adding $0.02 \mathrm{M}$ $\mathrm{HCl}$ and $10 \mathrm{ml} 1 \mathrm{M} \mathrm{NaF}$ solution and then titrated with $0.02 \mathrm{M} \mathrm{HCl}$ (Sahlemedhin and Taye, 2000). Exchangeable bases $\left(\mathrm{Ca}, \mathrm{Mg}, \mathrm{Na}\right.$ and $\mathrm{K}$ ) were extracted with $1 \mathrm{M} \mathrm{NH}_{4} \mathrm{OAc}$ at $\mathrm{pH} 7$ and then $\mathrm{Ca}$ and $\mathrm{Mg}$ were determined by atomic absorption spectrophotometer, while $\mathrm{K}$ and $\mathrm{Na}$ values were determined using flame photometer (Sahlemedhin and Taye, 2000). Effective cation exchange capacity (ECEC) was estimated through summation of exchangeable $\mathrm{Al}$ and basic cations.

The available $\mathrm{P}$ was extracted through Mehlich 3 method (Mehlich, 1984), the extracting solution with a $\mathrm{pH}$ of 2.5 containing $0.2 \mathrm{M} \mathrm{NH}_{4} \mathrm{Cl}, 0.2 \mathrm{M}$ acetic acid, $0.015 \mathrm{M} \mathrm{NH}_{4} \mathrm{~F}$ and $0.012 \mathrm{M} \mathrm{HCl}$. The extracted phosphorus was quantified colorimetrically using spectrophotometer. Water-soluble $\mathrm{P}$ was extracted by shaking a solution of $1 \mathrm{~g}$ soil and $40 \mathrm{ml}$ of deionized water for 1 hour (Curtin and Syers, 2001). The field water holding capacity of the soil was $27 \%$. The experimental soil had bulk density of $1.17 \mathrm{~g} \mathrm{~cm}^{-3}$, soil pH of 4.8 , available $\mathrm{P}$ of $2.7 \mathrm{mg} \mathrm{kg}^{-1}$ and $0.8 \mathrm{mg} \mathrm{kg}^{-1}$ water soluble P. Besides, its exchangeable acidity, $\mathrm{Al}, \mathrm{Ca}, \mathrm{Mg}, \mathrm{K}$ and $\mathrm{Na}$ were $1.8,1.5,3.2,2.75,0.72$ and $0.5 \mathrm{cmol}_{(+)} \mathrm{kg}^{-1}$, respectively.

\subsection{Experimental Design and Procedures}

Fifteen soil samples received $0,0.627,1.254,1.881$ and $2.508 \mathrm{~g}$ lime $\mathrm{kg}^{-1}$ soil equivalent to $0,1.1,2.2,3.3$ and 4.4 $\mathrm{t} \mathrm{ha}^{-1}$ lime each replicated thrice and arranged in a completely randomized design (CRD). The lime was thoroughly mixed with the soil through maintaining $90 \%$ of moisture content of the field capacity and then incubated for one month at constant room temperature and moisture. During experimental period, soil moisture loss due to evaporation was regularly compensated by adding equivalent amount of distilled water within four days interval and then mixed. After one month, the incubated soil samples were air dried and ground $(<2 \mathrm{~mm})$. Soil $\mathrm{pH}$, exchangeable basic cations, acidity and $\mathrm{Al}$, available and water soluble $\mathrm{P}$ were determined. 


\subsection{Statistical Analysis}

Values of the parameters were subjected to analysis of variance following the standard procedure of Gomez and Gomez (1984) using Statistical Analysis System (SAS) computer package v. 9.1 (SAS Institute Inc, 2002). Significant mean differences among treatments were delineated by least significant differences (LSD) at the probability level of $5 \%$.

\section{Results and Discussion}

\subsection{Morphological feature and category of the experimental soil}

The experimental soil had Nitic substances at lower depth thus, it categorized under Nitisol (NT) which derived from intensively weathered basalt rock, mainly tuffs of volcanic origin (FAO, 1984). Clay loam in texture and strongly acidic in reaction. Its consistency is very friable which crushes under very gentle pressure therefore, susceptible to soil erosion. Under moist condition it was slightly sticky since adheres to both thumb and finger but comes off one or the other rather cleanly and while it was plastic breaks immediately if bent into a ring. Granular structure type shifted towards blocky at lower depth (Table 1).

Table 1. Morphological description of the soil

\begin{tabular}{|c|c|c|}
\hline Horizon & Depth $(\mathrm{cm})$ & Profile description \\
\hline $\mathrm{Ap}$ & $0-20$ & $\begin{array}{l}\text { Dark red (2.5YR 3/6) dry; dark reddish brown }(2.5 \mathrm{YR} 3 / 4) \text { moist; clay loam; weak } \\
\text { to moderate, very fine to medium, granular; slightly hard, dry; very friable to friable, } \\
\text { moist; slightly sticky and slightly plastic, wet; many, medium to coarse roots; clear } \\
\text { and smooth boundary; non-calcareous (no effervescence with dilute } \mathrm{HCl}) ; \mathrm{pH}\left(\mathrm{H}_{2} \mathrm{O}\right) \\
\text { 4.6. }\end{array}$ \\
\hline $\mathrm{Bt}$ & $20-50$ & $\begin{array}{l}\text { Dark reddish brown }(2.5 \mathrm{YR} 3 / 4) \text { dry; dusky red }(2.5 \mathrm{YR} 3 / 2) \text { moist; clay; moderate to } \\
\text { strong, fine and medium, sub angular blocky; hard, dry; friable, moist; sticky and } \\
\text { plastic, wet; common fine roots; gradual and wavy boundary; non-calcareous (no } \\
\text { effervescence with dilute } \mathrm{HCl}) \text {; } \mathrm{pH}\left(\mathrm{H}_{2} \mathrm{O}\right) 4.8 \text {. }\end{array}$ \\
\hline $\mathrm{BC}$ & $50-100$ & $\begin{array}{l}\text { Dark reddish brown (5YR 3/3) dry; dark reddish brown (5YR 3/2) moist; clay; } \\
\text { medium to strong, medium to coarse, sub angular blocky; hard to very hard, dry; } \\
\text { friable to firm, moist; slightly sticky and plastic, wet; very few fine roots; diffuse and } \\
\text { irregular boundary; shiny ped faces; non-calcareous (no effervescence with dilute } \\
\mathrm{HCl} \text { ); pH (H2O) 4.8. }\end{array}$ \\
\hline $\mathrm{C}$ & $100-170$ & $\begin{array}{l}\text { Strong brown (7.5YR 5/6) dry; strong brown (7.5YR 5/6) moist; clay; strong, } \\
\text { medium and coarse, sub angular blocky; very hard, dry; firm, moist; sticky to very } \\
\text { sticky and very plastic, wet; no roots; diffuse and irregular boundary; shiny ped } \\
\text { faces; slightly calcareous (audible effervescence with dilute } \mathrm{HCl}) \text {; pH }(\mathrm{H} 2 \mathrm{O}) 4.8 \text {. }\end{array}$ \\
\hline
\end{tabular}

\subsection{Soil pH and Exchangeable Acidity}

Application of one ton ha ${ }^{-1}$ Dejen lime increased soil pH by 0.24 units on average (Table 2). In consent with the finding in this study, several reports (Sultana et al., 2009; Achalu et al., 2012; Abreha, 2013; Sarker et al., 2014) also indicated an increase in $\mathrm{pH}$ due to application of lime. In contrary, incubation slightly decreased the $\mathrm{pH}$ of the control by 0.03 unit. This decrease might be attributed to mineralization of, $\mathrm{NH}_{4}-\mathrm{N}$ into $\mathrm{NO}_{3}-\mathrm{N}$, which releases protons during incubation (Wang et al., 2011). Soil $\mathrm{pH}$ was significantly $(\mathrm{p}<0.01)$ increased due to the application rate of lime (Table 2). Soil $\mathrm{pH}$ of lime received samples increased by 0.35 to 0.58 units above the control treatment. In line with this, several authors revealed that soil $\mathrm{pH}$ of lime treated samples were raised in ranges between 0.5 and 1.5 units above the control treatment with comparable lime rates (Holford et al., 1994; Slattery et al., 1995; Abreha, 2013). However, the change in soil $\mathrm{pH}$ decreased progressively with increasing lime rates. A high $\mathrm{pH}$ increment per unit of lime $\left(0.39 \mathrm{pH} \mathrm{t}^{-1}\right)$ was observed at $1.1 \mathrm{t} \mathrm{ha}^{-1}$ rate, whereas lower $\mathrm{pH}$ increment per unit of lime $\left(0.15 \mathrm{pH} \mathrm{t}^{-1}\right)$ was observed at $4.4 \mathrm{t} \mathrm{ha}^{-1}$ lime due to high buffering effect of clay (Table 2). Similarly, Hoskins (1997) disclosed that acid ions in soil solution are small and neutralized by small amount of lime but the reserve acidity that is adsorbed on exchange sites is large, it replenishes hydrogen ions to the soil solution. Thus, soil pH cannot be raised to the desired level until this reserve acidity is neutralized. Some studies confirmed also low lime rate resulted in high $\mathrm{pH}$ increment per unit of lime while high lime rate showed low $\mathrm{pH}$ increment per unit lime (Fettell et al., 2007; Achalu et al., 2012).

Lime rates $(\mathrm{X})$ were non-linearly associated with soil $\mathrm{pH}(\mathrm{Y})\left(\mathrm{Y}=4.81+0.33 \mathrm{X}-0.045 \mathrm{X}^{2}, \mathrm{r}^{2}=0.91\right)$. In contrast with this, study report of Sultana et al. (2009) shows lime rates linearly increased soil $\mathrm{pH}(\mathrm{Y}=0.49 \mathrm{X}+$ $\left.5.06, \mathrm{r}^{2}=0.96\right)$. Lime rates were positively related with soil $\mathrm{pH}\left(\mathrm{r}^{2}=0.87\right)$. This is also supported by Henning (2008). Similarly, Sultana et al. (2009) and Diaz (2013) revealed that application of $2 \mathrm{t} \mathrm{ha}^{-1}$ lime significantly increased soil $\mathrm{pH}$ and enhanced crop growth on acidic soils. Besides, study report of Mahler (2002) indicated that maximum winter wheat yield was obtained in soil $\mathrm{pH}$ range between 5.1 and 5.4 depending on variety. Soil samples that received $2.2 \mathrm{t} \mathrm{ha}^{-1}$ lime increased $\mathrm{pH}$ from 4.77 to 5.32 , which is substantial for bread wheat production. 
Moreover, exchangeable acidity significantly $(\mathrm{p}<0.05)$ decreased with application of $\geq 2.2 \mathrm{t} \mathrm{ha}^{-1}$ Dejen lime (Table 2).

Exchangeable acidity of lime received treatments decreased by 0.5 to $0.8 \mathrm{cmol}_{(+)} \mathrm{kg}^{-1}$ below the control treatment, whereas acid saturation of these treatments decreased by $9.1 \%$ as compared to zero level lime received treatment. Similar findings corroborating with the present results were reported (Slattery et al., 1995; Abreha, 2013). According to Taye et al. (2007) cultivation of wheat, sorghum, barley and sweet potato crops is permissible in soils with $<10 \%$ acid saturation. This can be attained through application of $\geq 2.2 \mathrm{tha}^{-1}$ Dejen lime. Lime rates were negatively associated with exchangeable acidity $\left(r^{2}=-0.84\right)$, this is supported by the finding of Henning (2008).

Table 2. Effects of application dose of Dejen lime on soil pH and exchangeable acidity

\begin{tabular}{|c|c|c|c|c|c|c|}
\hline \multirow{2}{*}{$\begin{array}{l}\text { Lime } \\
\left(\mathrm{t} \mathrm{ha} \mathrm{h}^{-1}\right)\end{array}$} & \multicolumn{2}{|l|}{ Soil pH } & \multicolumn{2}{|c|}{ Exchangeable acidity $\left(\mathrm{cmol}_{(+)} \mathrm{kg}^{-1}\right)$} & \multicolumn{2}{|r|}{ ASP $(\%)$} \\
\hline & Mean & $\begin{array}{l}\text { per unit } \\
\text { (t) lime }\end{array}$ & Mean* & $\begin{array}{l}\text { per unit (t) } \\
\text { lime }\end{array}$ & Mean & $\begin{array}{l}\text { per unit } \\
\text { (t) lime }\end{array}$ \\
\hline 0 & $4.77^{\mathrm{c}}$ & & $1.75^{\mathrm{C}}$ & & $20.68^{c}$ & \\
\hline 1.1 & $5.20^{\mathrm{b}}$ & 0.39 & $1.25^{\mathrm{B}}$ & 0.45 & $11.96^{\mathrm{b}}$ & 7.93 \\
\hline 2.2 & $5.32^{\mathrm{ab}}$ & 0.25 & $1.03^{\mathrm{A}}$ & 0.33 & $8.69^{\mathrm{ab}}$ & 5.45 \\
\hline 3.3 & $5.34^{\mathrm{ab}}$ & 0.17 & $0.97^{\mathrm{A}}$ & 0.24 & $8.06^{\mathrm{a}}$ & 3.82 \\
\hline 4.4 & $5.43^{\mathrm{a}}$ & 0.15 & $0.95^{\mathrm{A}}$ & 0.18 & $7.53^{\mathrm{a}}$ & 2.68 \\
\hline $\mathrm{CV}(\%)$ & 1.05 & & 9.53 & & & \\
\hline $\operatorname{LSD}(p<0.01)$ & 0.15 & & 0.21 & & & \\
\hline
\end{tabular}

Means with the same letter within a column are insignificantly different at $\mathrm{p}<0.01, *=$ mean significantly different at $\mathrm{p}<0.05, \mathrm{ASP}=$ Acid saturation percentage

Lime rates $(\mathrm{X})$ decreased the exchangeable acidity $(\mathrm{Y})$ in a quadratic manner $\left(\mathrm{Y}=0.07 \mathrm{X}^{2}-0.46 \mathrm{X}+1.72, \mathrm{r}^{2}\right.$ $=0.89$ ). High soil $\mathrm{pH}$ induces neutralization of protons and hydrolysis of $\mathrm{Al}^{3+}$ to form $\mathrm{Al}$ hydroxide. Therefore, soil $\mathrm{pH}$ was negatively correlated with exchangeable acidity $\left(\mathrm{r}^{2}=-0.93\right)$.

\subsection{Available and Water Soluble Phosphorus}

Mehlich 3 (M3) available $P$ and water soluble $P$ values were significantly $(\mathrm{p}<0.01)$ increased in all application rates. Even though incubation slightly decreased available $\mathrm{P}$ (by $1.42 \mathrm{mg} \mathrm{kg}^{-1}$ ) due to slight decline in $\mathrm{pH}$, liming enhanced the concentration of $\mathrm{P}$ extracted by Mehlich 3 solution (Table 3 ). This shows that P sorptivity of most acidic soils decreases by liming thereby increasing the availability of $\mathrm{P}$ with increase in soil $\mathrm{pH}$ regardless of the extracting solution (Holford et al., 1994; Henning, 2008; Mbakaya et al., 2009). Values of soil pH and available $\mathrm{P}$ were associated exponentially (Figure 1). The change in available $\mathrm{P}$ decreased progressively with increasing rate of lime. Low lime rate elevated soil $\mathrm{P}$ at higher rate per unit lime, whereas high lime rate increased soil $\mathrm{P}$ at low rate per unit lime. Application of one ton $\mathrm{ha}^{-1}$ Dejen liming material elevated available P by $4 \mathrm{mg} \mathrm{kg}^{-1}$ on the average (Table 3).

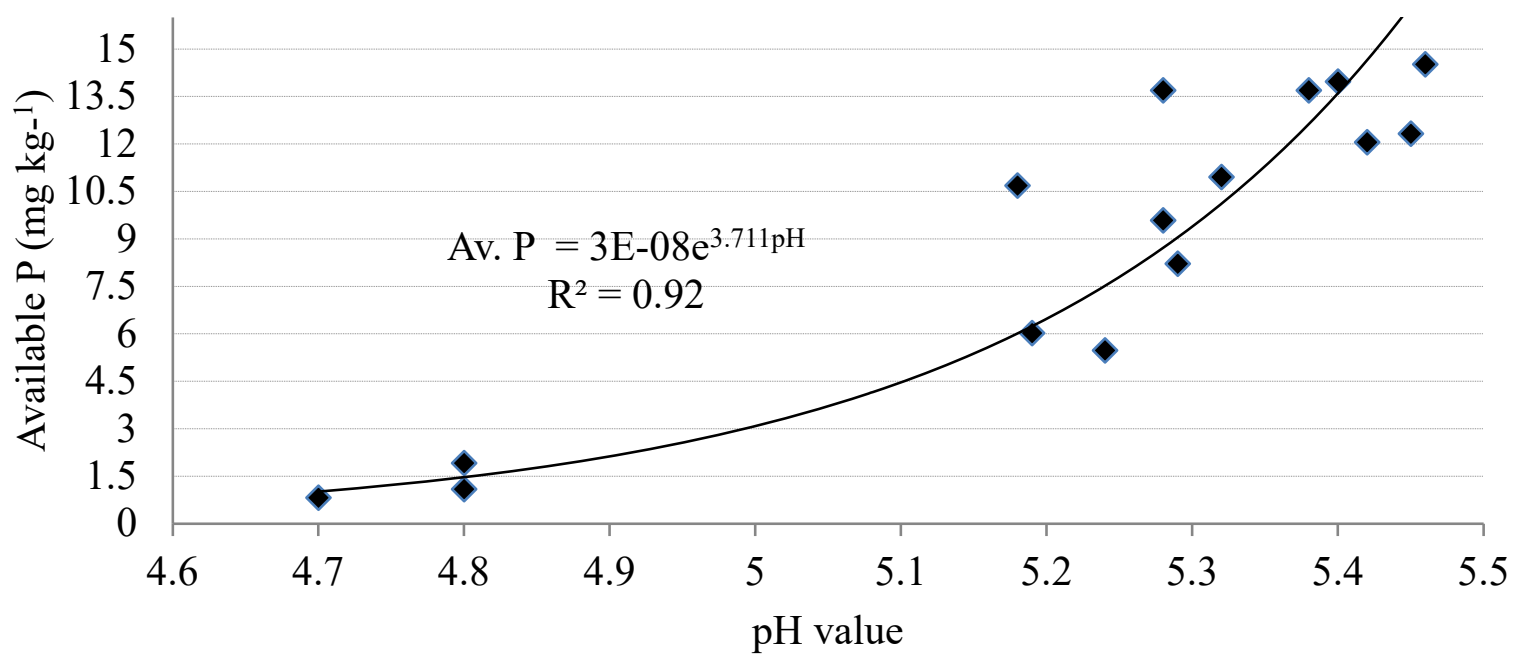

Figure 1. Effect of soil pH on available $P$

Liming increased available and water soluble P by $6.1-12.3$ and $1.1-2.1 \mathrm{mg} \mathrm{kg}^{-1}$, respectively. This could be attributed to $\mathrm{P}$ desorption from the fixed site and mineralization of organic $\mathrm{P}$ compounds (Molina and Fassbender, 1972; Haynes, 1982). The available $\mathrm{P}$ content of the soil was $7.1 \mathrm{mg} \mathrm{kg}^{-1}$ which is higher than that of water soluble P. The highest liming rate desorbed the maximum amount of M3 soil P $\left(12.3 \mathrm{mg} \mathrm{kg}^{-1}\right.$ or $21.6 \mathrm{~kg}$ P 
$\mathrm{ha}^{-1}$ in $15 \mathrm{~cm}$ depth) but the change rate was lower $\left(2.8 \mathrm{mg} \mathrm{P} \mathrm{kg}^{-1} \mathrm{t}^{-1}\right.$ lime$)$ than $1.1 \mathrm{t} \mathrm{ha}^{-1}$ lime. On the other hand, maximum water soluble $P$ was observed at $3.3 \mathrm{tha}^{-1}$ lime while progressive increase in lime rate $\left(4.4 \mathrm{tha}^{-1}\right)$ slightly decreased the water soluble $\mathrm{P}\left(0.33 \mathrm{mg} \mathrm{kg}^{-1}\right)$ (Table 3). In line with this, Curtin and Syers (2001) reported that water extractable $\mathrm{P}$ of soils tends to decrease with the application of high lime. Besides, lime incubation study conducted by Sarker et al. (2014) indicated that application of $2 \mathrm{t} \mathrm{ha}^{-1}$ lime desorbed more phosphorus in soil as compared with the application of $3 \mathrm{t} \mathrm{ha}^{-\mathrm{t}}$ lime.

Even though the $\mathrm{pH}$ of incubated soils was not higher than 5.43, some unavailable $\mathrm{P}$ may be extracted by Mehlich 3 (Table 3). It is also likely that Mehlich 3 method, which dissolve the strongly acidic ( $\mathrm{pH} 2.5$ ) compounds (Sharpley et al., 2004), might have overestimates the apparent increment of P availability. The substantial increment of Mehlich 3-P might be due to application of high lime rate since the soil has very low native $P$. According to Mallarino (2003), 21 to $25 \mathrm{mg} \mathrm{kg}^{-1} \mathrm{M} 3$ soil P (37 to $44 \mathrm{~kg} \mathrm{ha}^{-1}$ available P) is required for optimum growth of wheat. However, the Mehlich 3 soil $\mathrm{P}$ desorbed by application of maximum lime rate was $12.3 \mathrm{mg} \mathrm{kg}^{-}$ ${ }^{1}$, which according Mallarinols suggestion is far below the optimum P level required for successful productivity of wheat. Therefore, liming should be integrated with fertilization for optimum crop yield. Similar empirical studies conducted in different locations of the country indicated that wheat requires $30 \mathrm{~kg} \mathrm{P} \mathrm{ha}^{-1}$ (Damene, 2003; Melesse, 2007).

On the other hand, liming reduces $\mathrm{P}$ fixation capacity of soils, enhancing P fertilizer efficiency and increase the apparent recovery of $\mathrm{P}$ fertilizer (Donald, 2011). Application of lime nonlinearly increased available soil $\mathrm{P}$ and water soluble P. Available P correlated positively with soil $\mathrm{pH}\left(\mathrm{r}^{2}=0.90\right)$ and water soluble $\mathrm{P}\left(\mathrm{r}^{2}=0.79\right)$ while negatively to Al saturation percentage $\left(\mathrm{r}^{2}=-0.93\right)$.

Table 3. Effects of application dose of Dejen lime on available and water soluble $P$

\begin{tabular}{|c|c|c|c|c|}
\hline \multirow{2}{*}{$\begin{array}{l}\text { Lime } \\
\mathrm{t} \mathrm{ha}^{-1}\end{array}$} & \multicolumn{2}{|c|}{ Mehlich-P (mg kg-1) } & \multicolumn{2}{|c|}{ WSP $\left(\mathrm{mg} \mathrm{kg}^{-1}\right)$} \\
\hline & Value & $\begin{array}{l}\mathrm{P} \text { desorbed } \mathrm{t}^{-1} \\
\text { lime }\end{array}$ & Value & $\begin{array}{c}\mathrm{P} \text { desorbed } \mathrm{t}^{-1} \\
\text { lime }\end{array}$ \\
\hline 0 & $1.28^{\mathrm{c}}$ & & $0.66^{\mathrm{C}}$ & - \\
\hline 1.1 & $7.4^{\mathrm{b}}$ & 5.56 & $1.79^{\mathrm{B}}$ & 1.04 \\
\hline 2.2 & $10.5^{\mathrm{ab}}$ & 4.19 & $2.29^{\mathrm{AB}}$ & 0.74 \\
\hline 3.3 & $12.24^{\mathrm{ab}}$ & 3.32 & $2.73^{\mathrm{A}}$ & 0.63 \\
\hline 4.4 & $13.61^{\mathrm{a}}$ & 2.80 & $1.97^{\mathrm{B}}$ & 0.30 \\
\hline $\mathrm{CV}(\%)$ & 20.81 & & 11.05 & \\
\hline $\operatorname{LSD}(\mathrm{p}<0.01)$ & 5.13 & & 0.57 & \\
\hline
\end{tabular}

Means with the same letter in each column are insignificant at $\mathrm{p}<0.01$, M3 $=$ Mehlich 3 method, WSP $=$ Water Soluble Phosphorus

\subsection{Exchangeable Cations}

Exchangeable cations were significantly $(\mathrm{p}<0.01)$ affected by the application of lime. Application of $4.4 \mathrm{tha} \mathrm{h}^{-1}$ lime significantly $(\mathrm{p}<0.01)$ decreased exchangeable $\mathrm{Al}$, while it increased exchangeable $\mathrm{Ca}$ and ECEC of soil (Table 4). Lime application rate linearly increased exchangeable Ca content of the soil (Figure 2).

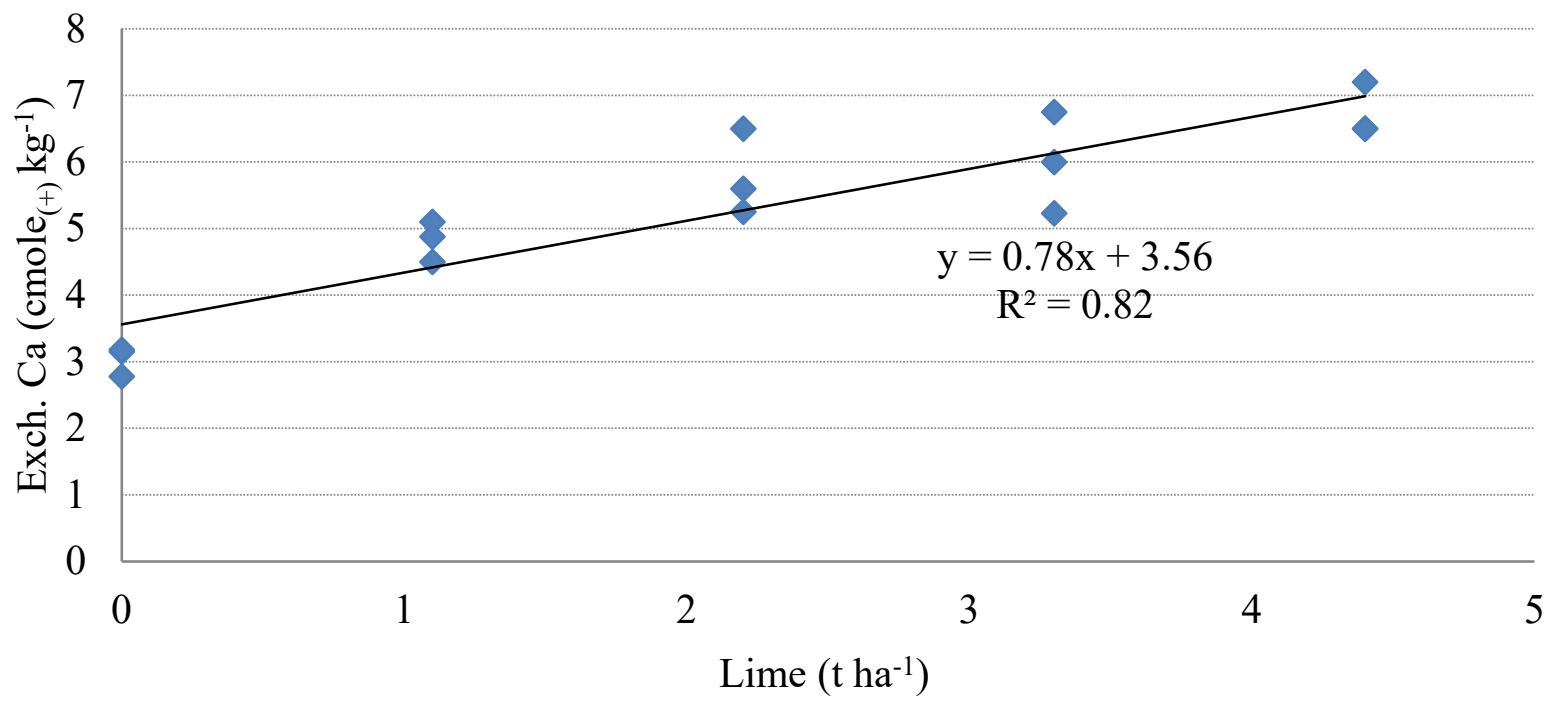

Figure 2. Lime rate and exchangeable Ca association

Exchangeable Al values of samples that received lime ranged between 0.32 and $1.2 \mathrm{cmol}_{(+)} \mathrm{kg}^{-1}$, whereas the 
control samples contained between 1.32 and $1.44 \mathrm{cmol}_{(+)} \mathrm{kg}^{-1}$. This indicates that application of lime at 1.1 to 4.4 $\mathrm{t} \mathrm{ha}^{-1}$ decreased the exchangeable $\mathrm{Al}^{3+}$ by $8-85 \%$. In line with this, Fageria (2009) and Abreha (2013) reported a significant decrease in $\mathrm{Al}$ due to lime application. Aluminum toxicity is the most growth-limiting factor in acid soils (Kinraide, 1995). Low soil $\mathrm{pH}$ enhances Al solubility, whereas high $\mathrm{pH}$ converts soluble $\mathrm{Al}$ into $\mathrm{Al}$ hydroxides and decreases Al concentration (Slattery et al., 1995). Soil pH and exchangeable Al are negatively and linearly related (Figure 3).

According to Haynes and Ludecke (1981), Parker et al.(1988), Bolan et al.(2003), Álvarez et al.(2009) and Abreha (2013) reports revealed that liming, through increasing soil $\mathrm{pH}$, decreased the concentration of $\mathrm{Al}$ and, intern, enhanced plant root growth and P uptake. According to Parker et al. (1988) and Upjohn et al. (2005) reports, the critical concentration of $\mathrm{Al}$ for wheat is $0.9 \mathrm{mg} \mathrm{kg}^{-1}$. In this study, this concentration level maintained through application of $\geq 2.2 \mathrm{t} \mathrm{ha}^{-1}$ Dejen lime. Exchangeable $\mathrm{Al}$ and soil $\mathrm{pH}$ were correlated negatively $\left(\mathrm{r}^{2}=-0.87\right)($ Table 5).

Table 4. Effects of application dose of Dejen lime on exchangeable cations $\left(\mathrm{cmol}_{(+)} \mathrm{kg}^{-1}\right)$

\begin{tabular}{|c|c|c|c|c|c|c|c|c|c|c|c|c|c|c|}
\hline \multirow{2}{*}{$\begin{array}{l}\text { Lime } \\
\text { t ha }^{-1}\end{array}$} & \multicolumn{2}{|c|}{ Exch. Ca } & \multicolumn{2}{|c|}{ Exch. Mg } & \multicolumn{2}{|c|}{ Exch. K } & \multicolumn{2}{|c|}{ Exch. $\mathrm{Na}$} & \multicolumn{2}{|c|}{ Exch. Al } & \multicolumn{2}{|c|}{$\mathrm{ECEC}$} & \multicolumn{2}{|c|}{ AlSP (\%) } \\
\hline & Mean & Rate & Mean & Rate & Mean & Rate & Mean & Rate & Mean & Rate & Mean & Rate & Mean & Rate \\
\hline 0 & $3.04^{\mathrm{d}}$ & & $2.81^{\mathrm{ns}}$ & & $0.73^{\text {ns }}$ & & $0.49^{\text {ns }}$ & & $1.41^{\mathrm{e}}$ & & $8.49^{b}$ & & $16.65^{\mathrm{e}}$ & \\
\hline 1.1 & $4.83^{c}$ & 1.63 & $3.15^{\mathrm{ns}}$ & 0.31 & $0.82^{\text {ns }}$ & 0.08 & $0.47^{\mathrm{ns}}$ & -0.02 & $1.15^{\mathrm{d}}$ & 0.24 & $10.41^{\mathrm{ab}}$ & 1.75 & $11.01^{\mathrm{d}}$ & -5.1 \\
\hline 2.2 & $5.78^{b}$ & 1.17 & $4.03^{\text {ns }}$ & 0.55 & $0.82^{\text {ns }}$ & 0.04 & $0.41^{\text {ns }}$ & -0.08 & $0.88^{c}$ & 0.24 & $11.32^{\mathrm{a}}$ & 1.29 & $7.46^{\mathrm{c}}$ & -4.2 \\
\hline 3.3 & $5.99^{\mathrm{ab}}$ & 0.89 & $4.13^{\mathrm{ns}}$ & 0.4 & $0.99^{\text {ns }}$ & 0.08 & $0.39^{\text {ns }}$ & -0.10 & $0.61^{b}$ & 0.24 & $12.11^{\mathrm{a}}$ & 1.09 & $5.07^{b}$ & -3.5 \\
\hline 4.4 & $6.73^{\mathrm{a}}$ & 0.84 & $4.15^{\mathrm{ns}}$ & 0.3 & $0.87^{\text {ns }}$ & 0.03 & $0.51^{\text {ns }}$ & 0.03 & $0.32^{\mathrm{a}}$ & 0.25 & $12.59^{\mathrm{a}}$ & 0.93 & $2.55^{\mathrm{a}}$ & -3.2 \\
\hline $\mathrm{CV} \%$ & 6.6 & & 18.0 & & 12.3 & & 27.3 & & 3.339 & & 7.2 & & 8.2 & \\
\hline LSD & 0.95 & & 1.81 & & 0.29 & & 0.34 & & 0.08 & & 2.19 & & 1.91 & \\
\hline
\end{tabular}

$\frac{\mathrm{p}<0.01}{\text { Means with the same letter in each column are insignificant at } \mathrm{p}<0.01, \text { Exch. }=\text { Exchangeable, ECEC }=\text { Effective }}$ Cation Exchange Capacity, AlSP = Al Saturation Percentage, CV $=$ Coefficient of Variation, LSD $=$ Least Significance Difference

Table 5. Correlation among soil chemical properties

\begin{tabular}{|c|c|c|c|c|c|c|c|c|c|c|c|}
\hline Parameter & $\mathrm{pH}$ & $\begin{array}{l}\text { Exchang } \\
\text { eable Al }\end{array}$ & $\begin{array}{l}\text { Exchange } \\
\text { Acidity }\end{array}$ & $\begin{array}{l}\text { Available } \\
\text { P }\end{array}$ & $\begin{array}{c}\mathrm{H}_{2} \mathrm{O} \text { soluble } \\
P\end{array}$ & $\begin{array}{c}\text { Exchange } \\
\text { able } \mathrm{Ca}\end{array}$ & $\begin{array}{l}\text { Exchang } \\
\text { eable Mg }\end{array}$ & $\begin{array}{l}\text { Exchang } \\
\text { eable } \mathrm{K}\end{array}$ & $\begin{array}{l}\text { Exchang } \\
\text { eable Na }\end{array}$ & ECEC & Al Saturation \% \\
\hline Exchangeable Al & $-0.87^{* *}$ & & & & & & & & & & \\
\hline Exchangeable Acidity & $-0.93^{* *}$ & $0.85^{\circ *}$ & & & & & & & & & \\
\hline Available P & $0.90^{\circ *}$ & $-0.89^{* *}$ & $-0.91^{* *}$ & & & & & & & & \\
\hline Water soluble $\mathrm{P}$ & $0.83^{\circ *}$ & $-0.68^{* *}$ & $-0.86^{* *}$ & $0.79^{* *}$ & & & & & & & \\
\hline Exchangeable $\mathrm{Ca}$ & $0.91^{* *}$ & $-0.89^{* *}$ & $-0.86^{* *}$ & $0.85^{* *}$ & $0.79^{* *}$ & & & & & & \\
\hline Exchangeable $\mathrm{Mg}$ & $0.64^{* *}$ & $-0.61^{\circ}$ & $-0.62^{\circ}$ & $0.69^{* *}$ & $0.61^{*}$ & $0.55^{*}$ & & & & & \\
\hline Exchangeable $\mathrm{K}$ & $0.56^{*}$ & $-0.49^{n s}$ & $-0.53^{\circ}$ & $0.49^{n s}$ & $0.58^{*}$ & $0.29^{\mathrm{ns}}$ & $0.33^{\text {ns }}$ & & & & \\
\hline Exchangeable $\mathrm{Na}$ & $-0.20^{\mathrm{ns}}$ & $0.05^{\mathrm{ns}}$ & $0.21^{\mathrm{ns}}$ & $-0.14^{\mathrm{ns}}$ & $-0.31^{\mathrm{ns}}$ & $-0.19^{\text {ns }}$ & $0.08^{\mathrm{ns}}$ & $-0.00^{n 5}$ & & & \\
\hline ECEC & $0.90^{\circ *}$ & $-0.84^{* *}$ & $-0.85^{* *}$ & $0.87^{* *}$ & $0.82^{* *}$ & $0.90^{\circ *}$ & $0.85^{* *}$ & $0.37^{\text {ns }}$ & $-0.03^{\text {ns }}$ & & \\
\hline Al Saturation \% & $-0.95^{* *}$ & $0.97^{\circ *}$ & $0.92^{* *}$ & $-0.93^{* *}$ & $-0.8^{* *}$ & $-0.94^{* *}$ & $-0.68^{* *}$ & $-0.5^{\mathrm{ns}}$ & $-0.09^{\text {ns }}$ & $-0.92^{* \bullet}$ & \\
\hline Acidity Saturation \% & $-0.96^{* *}$ & $0.84^{* *}$ & $0.98^{* *}$ & $-0.91^{* *}$ & $-0.88^{* *}$ & $-0.90^{+*}$ & $-0.68^{* *}$ & $-0.5^{n 5}$ & $0.11^{\mathrm{ns}}$ & $-0.91^{* \bullet}$ & $0.94^{* *}$ \\
\hline
\end{tabular}

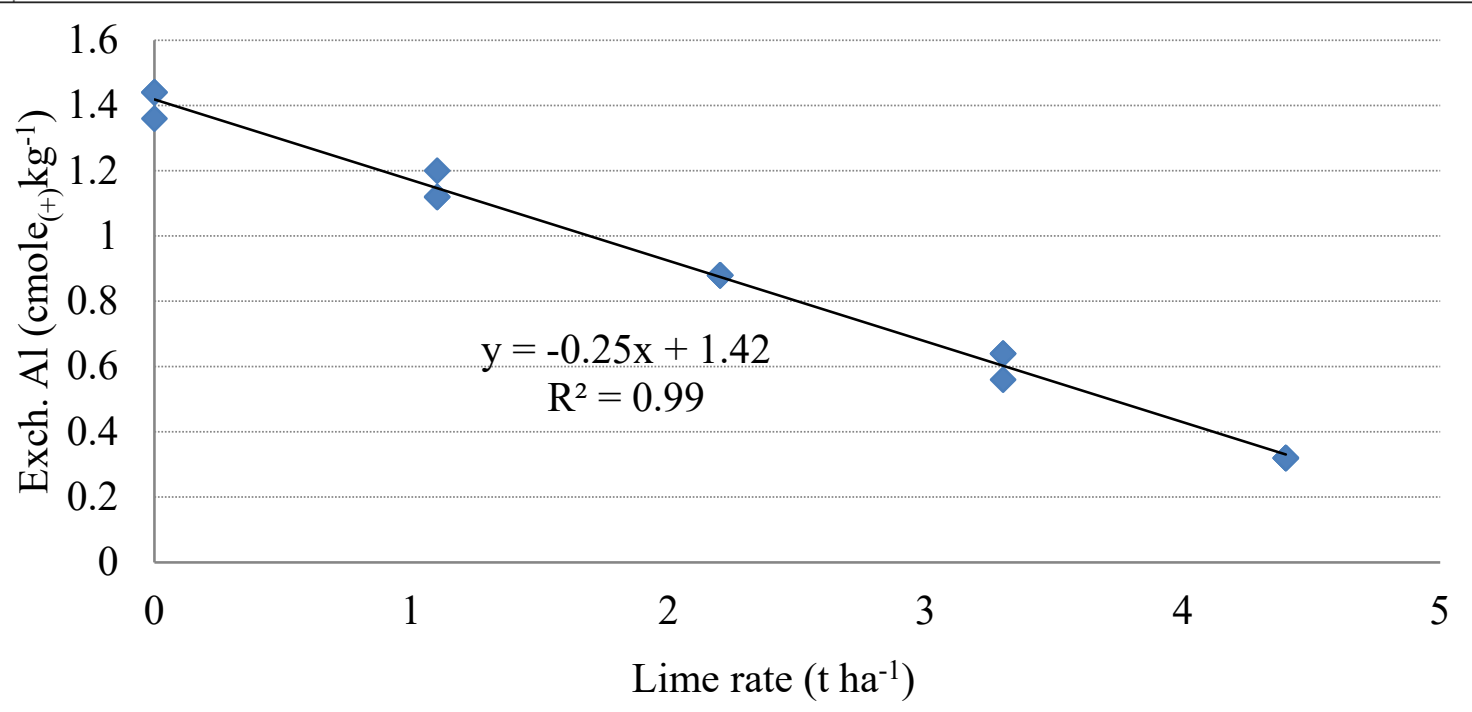

Figure.3. Lime rate and extractable $\mathrm{Al}$ association

\section{Conclusions}

Dejen liming material application significantly increased soil $\mathrm{pH}$, available $\mathrm{P}$ and exchangeable Ca but significantly decrease exchangeable acidity and exchangeable Al of acidic soils of Gozamin District. The overall studied parameters of the soil indicated that application of $\geq 2.2 \mathrm{t} \mathrm{ha}^{-1}$ Dejen lime substantially improved $\mathrm{pH}$, 
exchangeable acidity, exchangeable Al, Ca, basic cations, Mehlich 3 and water soluble $\mathrm{P}$ properties of acidic soil but supplementary plant nutrient is essential for optimum crop yield in the study area.

\section{References}

Abreha Kidanemariam. 2013. Soil acidity characterization and effects of liming and chemical fertilization on dry matter yield and nutrient uptake of wheat (Triticum aestivum L.) on soils of Tsegede District, northern Ethiopia. Doctoral Dissertation, Haramaya University, Haramaya, Ethiopia.

Achalu Chimdi, Heluf Gebrekidan, Kibebew Kibret and Abi Taddesse. 2012. Effects of liming on acidity-related chemical properties of soils of different land use systems in western Oromia, Ethiopia. World Journal of Agricultural Sciences, 6: 560-567.

Agbenin, J.O. 1996. Phosphorus sorption by three cultivated Savanna Alfisols as influenced by soil pH. Fertilizer Research, 44: 107-112.

Agriculture Information Center, 2002. Liming an Acid Soil. (http://www.agric.gov.ab.ca.) Accessed on April 25, 2013.

Álvarez, E. Viadé, A. and Marcos, M.L. 2009. Effect of liming with different sized limestone on the forms of aluminum in a Galician soil (NW Spain). Geoderma, 152: 1-8. doi:10.1016/j.geoderma.2009.04.011.

Ashenafi Gedamu. 2008. Triticale production in Ethiopia-its impact on food security and poverty alleviation in the Amhara region. Doctoral Dissertation, Kassel University, Kassel, Germany.

Birru Yitaferu and Heluf Gebrekidan. 2003. Kinetics of phosphorus for some selected soils of the north-western highlands of Ethiopia. In: Tilahun Amede and Eylachew Zewdie (eds.), 2003, Challenges of Land Degradation to Agriculture in Ethiopia, Proceedings of the $6^{\text {th }}$ ESSS (Ethiopian Society of Soil Science) Conference, February 28 to March 1, 2002. Addis Ababa, Ethiopia.

Blake, G.R. 1965. Methods of Soil Analysis. American Society of Agronomy, Madison, Wisconsin, USA, 9: $374-$ 399.

Bolan, N.S. Adriano, D.C. and Curtin, D. 2003. Soil Acidification and Liming Interactions with Nutrient and Heavy Metal Transformation and Bioavailability, Advances in Agronomy, Volume 78: Academic Press. dio 10.1016/5006.

Buresh, R.J. Smithson, P.C. and Heliums, D.T. 1997. Building soil phosphorus capital in Africa. In: Replenishing Soil Fertility in Africa. SSSA Special Buresh, R. Sanchez, P.A. and Calhoun, F. (eds.), American Society of Agronomy and Soil Science Society, 1- 677.

CSA (Central Statistical Agency). 2005. The Federal Democratic Republic of Ethiopia Central Statistical Agency. 2004/05 season agricultural sample survey, volume I, report on area and production of major crops (private peasant holdings, meher season), Addis Ababa, Ethiopia.

CSA (Central Statistical Agency). 2006. The Federal Democratic Republic of Ethiopia Central Statistical Agency. 2005/06 season agricultural sample survey, volume I, report on area and production of major crops (private peasant holdings, meher season), Addis Ababa, Ethiopia.

CSA (Central Statistical Agency). 2007. The Federal Democratic Republic of Ethiopia Central Statistical Agency. 2006/07 season agricultural sample survey, volume I, report on area and production of major crops (private peasant holdings, meher season), Addis Ababa, Ethiopia.

Curtin, D. and Syers, J. 2001. Lime induced changes in indices of soil phosphate availability. Soil Science Societies of America Journal, 65: 147-152.

Damene Darota. 2003. Yields response of bread wheat (Triticum aestivum L.) to applied level of N and P fertilizer on Nitisols Dewuro Zone, southern Ethiopia. MSc. Thesis, Alemaya University, Haramaya, Ethiopia.

Devers, V. 2011. Phosphate homeostasis and novel microRNAs are involved in the regulation of the Arbuscular Mycorrhizal symbiosis in Medicago truncatula. Doctoral Dissertation, University of Potsdam, Germany.

Diaz, R.D. 2013. Why Lime Effective Calcium Carbonate (ECC) Matters. Lime can improve acid soils for optimum wheat production. South Central Kansas Lime.

Donald, B. 2011. Soil pH: What it means. State University of New York College of Environmental Science and Forestry. (http://www.esf.edu.) Accessed on December 21, 2014.

Fageria, N. 2009. The Use of Nutrients in Crop Plants. CRC press Taylor and Francis Group, LLC Boca Raton, 145.

Fageria, N. and Santos, A. 2008. Yield physiology of dry bean. Journal of Plant Nutrition, 31: 983-1004.

FAO (Food and Agriculture Organization). 1998. World Reference Base for Soil Resources. 84 World Soil Resources Reports, International Society of Soil Science, International Soil Reference and Information Centre (ISRIC), Rome, Italy.

FAO (Food and Agriculture Organization). 2006. Plant nutrition for food security, a guide for integrated nutrient management, FAO fertilizer and plant nutrition bulletin 16. Food and Agriculture Organization of the United Nations, edited by Roy, R.N. Finck, A. Blair, J. and Tandon, S. Rome, Italy.

Fettell, N. Evans, C. Carpenter, D. and Brockwell, J. 2007. Residual effects from lime application on soil pH, 
Rhizoidal population and crop productivity in dry-land farming systems of central New South Wales. Australian Journal of Experimental Agriculture, 47: 608-619.

Foy, C. 1984. Physiological effects of hydrogen, aluminum, and manganese toxicities in acid soil. 57-97. In: Adams, F. (ed.), Soil Acidity and Liming. Second Edition Agronomy monograph. 12. ASA, CSSA, and SSSA, Madison.

Gilbert, N. 2009. The Disappearing Nutrient. Nature, 461: 716-718.

Gomez, K. and Gomez, A. 1984. Statistical Procedure for Agricultural Research, Second Edition. A Wiley InterScience Publication, New York, USA.

Haynes, R.J. 1982. Effects of liming on phosphate availability in acid soils. Plant and Soil, 68: 289-308.

Haynes, R.J. 1984. Lime and phosphate in the soil-plant system. Advances in Agronomy, 37: 249-315.

Haynes, R J. and Ludecke. T E. 1981. Yield, root morphology and chemical composition of two pasture legumes as affected by lime and phosphorus applications to an acid soil. Plant and Soil, 62: 241-254.

Henning, S.J. 2008. Crop and soil responses to rates of lime. Iowa State University, Northeast Research and Demonstration Farm, ISRF08-13.

Holford, I. 1997. Soil phosphorus: its measurement, and its uptake by plants. Australian Journal of Soil Research, 35: 227-39.

Holford, I. Schweitzer, B. and Crocker, G. 1994. Long-term effects of lime on soil phosphorus solubility and sorption in eight acidic soils. Australian Journal of. Soil Research, 32: 795-803.

Horst, W. Kamh, M. Jibrin, J. and Chude, V. 2001. Agronomic measures for increasing P availability to crops. Plant and Soil, 237: 211-223.

Hoskins, B.R. 1997. Soil Testing Handbook for Professionals in Agriculture, Horticulture Nutrient and Residuals Management Third Edition. Maine Forestry \& Agricultural Experiment Station, University of Maine. (http://www.anlab.umescl.maine) Accessed on September 14, 2015.

IOANRS (Investment office for Amhara National Regional State), 2006. Potential survey, identification of opportunities and preparations of projects profiles and feasibility studies, part one potential assessment, unpublished soil survey study report by Development Studies Association (DSA) and Shawel Consult International (SCI).

Keerthisinghe, F. Zapata, P. Chalk, P. and Hocking, P. 2001. Integrated approach for improved P nutrition of plants in tropical acid. Plant nutrition-Food security and sustainability of agro-ecosystems. Kluwer Academic Publishers, Dordrecht, the Netherlands, 974 975.

Kinraide, T.B. 1995. Identity of the rhizotoxic aluminum species, pp. 717-728. In: Date, R.A. Grundon, N.J. Rayment, G.E. Probert, M.E. (eds.), Plant-Soil Interactions at Low pH. Kluwer Academic Publishers, Dordrecht, the Netherlands.

Kinraide, T.B., 2003. Toxicity factors in acidic forest soils: attempts to evaluate separately the toxic effects of excessive $\mathrm{Al} 3$ +and $\mathrm{H}+$ and in sufficient $\mathrm{Ca} 2+$ and $\mathrm{Mg} 2+$ upon root elongation. European Journal of Soil Science, 549, 323-333.

Kisinyo, P.O. Othieno, C.O. Okalebo, J.R. Kilpsat, M.J. Serema, A.K. and Obiero, D.O. 2005. Effects of lime and phosphorus application on early growth of Leucaena in acid soils. Conference Proceedings, 7: 1233-1236.

Kisinyo, P.O. Gudu, S.O. Othieno, C.O. Okalebo, J.R. and Opala, P.A. 2012. Effects of lime, phosphorus and rhizobia on Sesbania sesban performance in a western Kenyan acid soil. African Journal of Agriculture Research, 7: 2800-2809.

Lungu, O. Temba, J. Chirwa, B. and Lungu, C. 1993. Effects of lime and farmyard manure on soil acidity and maize growth on an acid Alfisol from Zambia. Tropical Agriculture, 70: 309-314.

Mahler, R.L. 2002. Impacts and management of soil acidity under direct seed systems status and effects on crop production. Pacific Northwest Conservation Tillage Systems Information Source. Direct Seed Conference. January 16-18, 2002. (http://www.wsu.edu.) Accessed on January 17, 2014.

Mallarino, A. 2003. New interpreting results of the Mehlich- \# 3 ICP soil phosphorus test. In: Integrated Crop Management, IC-490 (24)-November 17, 2003, Iowa State University.

Marschner, P. 2012. Marschner's Mineral Nutrition of Higher Plants, $3^{\text {rd }}$ Edition, Elsevier Ltd. The University of Adelaide, Australia.

Mbakaya, S. Okalebo, J. Muricho, M. and Lumasayi, S. 2009. Effects of liming and inorganic fertilizers on maize yield in Kakamega north and Ugunja Districts, western Kenya. Conference presented paper, pp 123-129.

Mehlich, A. 1984. Mehlich III soil test extractant: A modification of Mehlich II extractant. Communications in Soil Science and Plant Analysis, 15: 1409-1416.

Melakeberhan Haddish, Bird, G.W. and Jones A. L. 2001. Soil pH affects nutrient balance in cherry rootstock leaves. Horticultural Science, 36(5): 916-917.

Melesse Harfe. 2007. Response of bread wheat (Triticum aestivum L.) varieties to $\mathrm{N}$ and $\mathrm{P}$ fertilizer rates in Ofla District, southern Tigray, Ethiopia. MSc. Thesis, Haramaya University, Haramaya, Ethiopia.

Mesfin Abebe. 2007. Nature and Management of Acid soils in Ethiopia. Addis Ababa, Ethiopia. 
Ministry of Agriculture and Rural Development, 2006. Land degradation Conference report in March, 2006, Unpublished Amharic version, Addis Ababa, Ethiopia.

Miressa Duffera and Robarge, W.P. 1999. Soil characteristics and management effects on phosphorus sorption by high land plateau soils of Ethiopia. Soil Science Societies of America Journal, 63: 1455-1462.

Molina, R. and Fassbender, H.W. 1972. Effect of liming on the forms and availability of phosphorus and its uptake by plants in six Costa Ricn soils. Zeitschrift für Pflanzenernährung und Bodenkunde, 132: 81-87.

Naidu, R. Syers, J. Tillman, R. and Kirkman, J. 1990. Effect of liming on phosphate sorption by acid soils. Journal of Soil Science, 41: 165-175.

Nziguheba, G. 2007. Overcoming phosphorus deficiency in soils of Eastern Africa: recent advances and challenges. In; Bationo A. (ed.) Advances in Integrated Soil Fertility Management in Sub-Saharan Africa: Challenges and Opportunities, 149-160.

Nziguheba, G. Merckx, R. and Palm, C. 2002. Soil phosphorus dynamics and maize response to different rates of phosphorus fertilizer applied to an Acrisol in western Kenya. Plant and Soil, 243: 1-10.

Parker, D.R. Kinraide, T.B. and Zelazny, L.W. 1988. Aluminum speciation and phytotoxicity in dilute hydroxylaluminum solutions. Soil Science Society of American Journal, 52: 438-444.

Pinkerton, A., and Simpson, J. R. 1986. Interactions of surface drying and subsurface nutrients affecting plant growth on acidic soil profiles from an old pasture. Australian Journal of Experimental Agriculture, 26, 681689.

Rajkishore, R. 2005. Response of groundnut genotypes to lime and phosphorus levels in coastal alluvial soil of north Karnataka. MSc. Thesis, Dharwad University of Agricultural Sciences, India.

Sahlemedhin Sertsu and Ahmed Ali. 1983. Phosphorus sorption characteristics of some Ethiopian soils. Ethiopian Journal of Agricultural Science, 5: 1-13.

Sahlemedhin Serstu and Taye Bekele. 2000. Procedure for soil and plant analysis. National Soil Research Centre, Ethiopian Agricultural Research Organization, Addis Ababa, Ethiopia.

Sanchez, P. Shepherd, K. Soule, M. Place, F. Buresh, R. Izac, A. Mokwunye, A. Kwesiga, F. Ndiriu, C. and Woomer, P. 1997. Soil fertility replenishment in Africa: an investment in natural resource capital. In: Buresh, R. Sanchez, P. and Calhoun, Ž (eds.). Replenishing Soil Fertility in Africa, Special Publication. Soil Science Society of America, Madison, USA, 51: 111-149.

Sarker, A. Kashem, A. Osman, K.T. Hossain, I. and Ahmed, F. 2014. Evaluation of available phosphorus by soil test methods in an acidic soil incubated with different levels of lime and phosphorus. Open Journal of Soil Science, 4, 103-108. doi.org/10.4236/ojss. 2014.43014.

SAS Institute Inc. 2002. SAS User's Guide, Statistics Version 9.1 (ed.), SAS Inst. Cary, NC, USA.

Sato, S. 2003. Phosphorus sorption and desorption in a Brazilian Ultisol: effects of $\mathrm{pH}$ and organic anions on phosphorus bioavailability. Doctoral Dissertation, University of Florida, Florida, USA.

Sato, S. and Comerford, N. 2005. Influence of soil pH on inorganic phosphorus sorption and desorption in a humid Brazilian Ultisol, Sociedade Brasileira de Ciência do Solo. doi.org/10.1590/S0100-06832005000500004.

Sharpley, A.N. McDowell, R.W. and Kleinman, P.J.A. 2004. Amounts, forms and solubility of phosphorus in soils receiving manure. Soil Science Society of America Journal, 68: 2048-2057.

Singh, B. and Lal, R. 2005. Phosphorus management in low input agricultural systems. In: Sims, J. and Sharpley, A. (eds.), Phosphorus: Agriculture and the Environment, ASA, CSSA, SSSA, Madison. Agronomy monograph, 46: 729-759.

Slattery, W. Morrison, R. and Coventry, R. 1995. Liming effects on soil exchangeable and soil solution cations of four soil types in north-eastern Victoria. Australian Journal of Soil Research, 33: 277-295.

Solomon Dawit, Lehmann, J. Tekalign Mammo, Fritzsche, F. and Zech, W. 2002. Phosphorus forms and dynamics as influenced by land use changes in the sub-humid Ethiopian highlands. Geoderma, 105: 21-48.

Sultana, B.S. Mian, M.H. Islam, M.R. Rahman, M.M. Sarker, B.C. and Zoha, M.S. 2009. Effect of liming on soil properties, yield and nutrient uptake by wheat. Current World Environment, 4(1): 39-47.

Sumner, M. and Noble, A. 2003. Soil acidification: The World story. 1-28. In: Rengel, Z. (ed.), Handbook of Soil Acidity. New York, NY, USA: Marcel Dekker, Inc.

Taye Bekele, Zebene Mikru and Abayneh Esayas. 2007. Laboratory procedure for the determination of lime requirement and calcium carbonate content in lime. National Soil Research Center Ethiopian Institute of Agricultural Research, unpublished laboratory manual.

Tekalign Mammo and Haque, I. 1991. Phosphorus status of some Ethiopian soils. III. evaluation of soil test methods for available phosphorus. Tropical Agriculture, 68: 51-56.

Thomason, W.E. Wynn, K.J. Freeman, K.W. Lukina, E.V. Mullen, R.W. Johnson, G.V. Westerman, R.L. and Raun, W.R. 2001. Effect of chloride fertilizers and lime on wheat grain yield and take-all disease. Journal of Plant Nutrition, 24: 683-692.

Upjohn, B. Fenton, G. and Conyers, M. 2005. Soil Acidity and Liming. Agfact AC.19, $3^{\text {rd }}$ edition AGDEX 534, State of New South Wales, Wagga Agricultural Institute, 1-24. 
Wang, N. Xu, R.K. and Li, J.Y. 2011. Amelioration of an acid Ultisol by agricultural by-products. Land Degradation Development, 22: 513-518.

Weil, R.R. 2000. Soil and plant influences on crop response to two African phosphate rocks. Agronomy Journal, 92: $1167-1175$

Whitehead, D.C. 2000. Nutrient Elements in Grassland Soil-Plant-Animal Relationships. Department of Soil Science, Institute for Grassland and Environmental Research. ISBN 0-85199-437-7. CABI Publishing, Oxon and New York, UK and USA. doi: 10.1016/s0016-7061(01)00052-0.

Wildey, T. 2003. The influence of seed placed lime to reduce the acidifying effects of nitrogen fertilizers in direct seeding systems. MSc Thesis, Washington State University, Pullman, USA.

Wissuwa, M. 2003. How do plants achieve tolerance to phosphorus deficiency? Small Causes with big effects. American Society of Plant Biologists, 133: 1947-1958. 